\title{
Seabird associations with mesoscale eddies: the subtropical Indian Ocean
}

\author{
K. David Hyrenbach ${ }^{1,5, *}$, Richard R. Veit ${ }^{2}$, Henri Weimerskirch ${ }^{3}$, George L. Hunt $\mathrm{Jr}^{4,5}$ \\ ${ }^{1}$ Duke University Marine Laboratory, 135 Duke Marine Lab. Rd., Beaufort, North Carolina 28516, USA \\ ${ }^{2}$ Biology Department, CSI-CUNY, 2800 Victory Boulevard, Staten Island, NewYork 10314, USA \\ ${ }^{3}$ Centre d'Etudes Biologiques de Chizé, Centre Nationale Research Scientifique, 79360 Villiers en Bois, France \\ ${ }^{4}$ Department of Ecology and Evolutionary Biology, University of California Irvine, Irvine, California 92697, USA \\ ${ }^{5}$ School of Aquatic and Fishery Sciences, University of Washington, Box 355020, Seattle, Washington 98195, USA
}

\begin{abstract}
We investigated seabird-eddy associations in subtropical waters of the southern Indian Ocean during a summer (January) cruise from Amsterdam Island to Western Australia. To determine habitat associations and to enable predictions about foraging strategies, we related the distributions of satellite altimetry data (sea surface height anomalies) to the 3 most abundant taxa in the study area: terns (sooty Sterna fuscata and bridled S. anaethetus) and shearwaters (wedge-tailed Puffinus pacificus) were significantly more common and numerous within convergence zones. However, a step-wise logistic regression model revealed that these seabirds were more strongly associated with other habitat variables, including the distance to breeding colonies and warm sea surface temperature conditions. Great-winged petrels Pterodroma macroptera were widely scattered and did not show associations with convergences or divergences. These contrasting results highlight the need to consider smaller-scale hydrographic features, such as frontal systems, when quantifying seabird associations with mesoscale eddies. Large-scale patterns of ocean circulation and mesoscale variability also seem to play a critical role in determining the extent of seabird-eddy associations. In contrast with previous studies, which have focused on dynamic frontal regions and energetic current systems, we surveyed a region of weak mesoscale variability north of the Subtropical Convergence zone.
\end{abstract}

KEY WORDS: Altimetry $\cdot$ Indian Ocean $\cdot$ Mesoscale eddies $\cdot$ Remote sensing $\cdot$ Seabirds $\cdot$ Sea surface height anomalies

Resale or republication not permitted without written consent of the publisher

\section{INTRODUCTION}

Eddies are large $(\sim 100 \mathrm{~km}$ diameter $)$, long-lived $(\sim$ months), and pervasive features in the world's oceans (Owen 1981, Robinson 1983, Oschlies \& Garcon 1998). These conspicuous hydrographic features influence the horizontal and vertical distributions of the chemical (e.g. nutrients), physical (e.g. sea surface temperature [SST]) and biological (e.g. chlorophyll a [chl a] concentration) properties in pelagic systems (Yoder et al. 1981, McGillicuddy et al. 1998, Seki et al. 2001, Endo \& Wiebe 2005). Moreover, areas of upwelling and downwelling driven by eddy vorticity stimulate primary productivity and aggregate buoyant and weakly swimming organ- isms, including neuston, plankton, and fish (Olson \& Backus 1985, Franks 1992, Strass 1992, Davis et al. 2002).

The ecological significance of these mesoscale features is underscored by evidence that regions where permanent (e.g. Costa Rica Dome; Fiedler et al. 1991) and transient (e.g. Oyashio-Kuroshio confluence; Uda \& Ishino 1958) eddies predictably occur are characterized by elevated primary production, high zooplankton biomass, and the aggregation of upper-trophic predators (Yoder et al. 1981, Haney 1986a, Seki et al. 2001, Davis et al. 2002). The fertilizing effects of eddies may be especially important in tropical and subtropical regions, where winter mixing cannot replenish nutrients in the photic zone by eroding the deep ( $>50 \mathrm{~m})$ 
thermocline (McGillicuddy et al. 1998, Oschlies \& Garcon 1998, Seki et al. 2001). These relatively unproductive oceanic regions support far ranging uppertrophic predators that forage on widely dispersed resources and frequently exploit prey concentrated at the periphery of mesoscale eddies (Nel et al. 2001, Polovina et al. 2004, Weimerskirch et al. 2004).

Seabird distributions are clearly influenced by mesoscale hydrographic features (Hunt \& Schneider 1987). In particular, many species forage and aggregate at hydrographic fronts and mesoscale eddies (Haney \& McGillivary 1985, Abrams \& Lutjeharms 1986, Haney 1986b, Nel et al. 2001, Weimerskirch et al. 2004). However, previous vessel-based studies have often focused on the importance of specific types of eddies (e.g. cyclonic vs. anti-cyclonic), without considering the spatial heterogeneity within and among these large habitat features. For example, the smaller-scale $(\sim 10 \mathrm{~s}$ $\mathrm{km})$ fronts at the periphery of mesoscale $(\sim 100 \mathrm{~km})$ eddies may be important areas where seabirds aggregate to forage on concentrated prey. Because regions of surface convergence and divergence are characterized by gradients in SST and chl a concentration, it is imperative to consider seabird-eddy associations in the context of smaller-scale gradients in water-mass properties (Weller 1985, Haney 1986a,b, Yoder et al. 1994, Ribic et al. 1997).

In the Indian Ocean, seabird-eddy associations have been documented in tropical (e.g. Mozambique Current, 35 to $44^{\circ} \mathrm{E}$ ) and subtropical waters (e.g. Agulhas Return Current, 20 to $80^{\circ} \mathrm{E}$ ) (Abrams \& Lutjeharms 1986, Nel et al. 2001, Weimerskirch et al. 2004). The present study addresses seabird-eddy associations within a region of weak mesoscale variability in the eastern Indian Ocean (80 to $115^{\circ} \mathrm{E}$ ) (Park \& Gambéroni 1995). First, we set out to determine whether marine birds are associated with mesoscale hydrographic features, defined in terms of sea surface height anomalies (SSHA). Second, we quantify which habitat features (color and temperature fronts, convergence/divergence zones) best explain seabird distributions. To determine whether different seabird groups with specific morphological and behavioural specialisations differ in their oceanographic habitat associations, we relate the sightings of 3 focal taxa (the most abundant species) to the concurrent patterns of SSHA, $\mathrm{SST}$, and chl a derived from remote sensing imagery.

\section{MATERIALS AND METHODS}

Study area. We analyzed a dataset collected during a 5 d cruise (January 17 to 21, 2003) from Amsterdam Island $\left(37^{\circ} 52^{\prime} \mathrm{S}, 77^{\circ} 32^{\prime} \mathrm{E}\right)$ to Perth, Western Australia (WA) $\left(32^{\circ} 01^{\prime} \mathrm{S}, 115^{\circ} 47^{\prime} \mathrm{E}\right)$. The cruise track, which spanned from $410 \mathrm{~km}$ northeast of Amsterdam Island to $233 \mathrm{~km}$ southwest of Western Australia, surveyed deep (3 to $5 \mathrm{~km}$ depth) waters north of the Subtropical Convergence zone (Fig. 1).

Seabird surveys. Two of us (K.D.H. \& R.R.V.) surveyed marine birds during daylight hours from the flying bridge of the RV 'Marion Dufresne', eye height of $26 \mathrm{~m}$ above the sea surface, while the vessel cruised at speeds between 10 and 15 knots (18.5 to $27.7 \mathrm{~km} \mathrm{~h}^{-1}$ ). Following standardized strip transect methods (Tasker et al. 1984), we logged all birds sighted within $300 \mathrm{~m}$ of the side of the vessel with best visibility (i.e. least sun glare or wind) into a field computer with a temporal resolution of $0.1 \mathrm{~min}$. Individuals that followed the ship were recorded when first encountered and ignored thereafter. We aggregated the continuous seabird observations into $9 \mathrm{~km}$ bins (198), and quantified the occurrence (presence/absence) and the density of each species by dividing the total number of individuals sighted (all behaviors combined) by the area surveyed $\left(\mathrm{km}^{2}\right)$. Our analyses focus on the 3 numerically dominant taxa (Table 1).

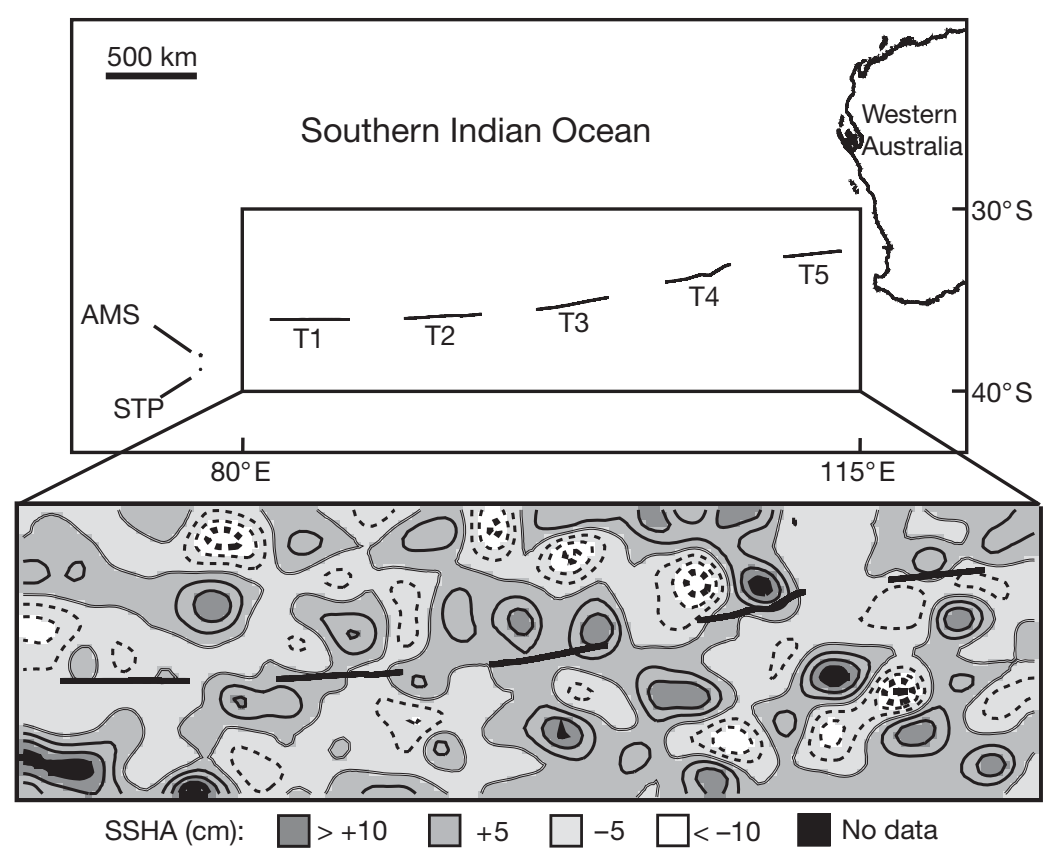

Fig. 1. Map of the study area showing the location of Amsterdam Island (AMS) and St. Paul Island (STP) and the 5 daily survey transects (T1 to T5). The insert depicts the contours of sea surface height anomalies (SSHA) from satellite altimetry, indicative of the distribution of mesoscale eddies, at the midpoint of the survey (January 19, 2003) 
Table 1. Summary of seabird taxa recorded across the southern Indian Ocean (January 17 to 21, 2003), showing the total number of birds and the proportion (\%) within areas of convergence and divergence, defined by daily sea surface height anomalies (SSHA)

\begin{tabular}{|c|c|c|c|c|}
\hline Common name & Species & Total & Convergence (\%) & Divergence $(\%)$ \\
\hline Wedge-tailed shearwater & Puffinus pacificus & 823 & 89.2 & 10.8 \\
\hline Great-winged petrel & Pterodroma macroptera & 351 & 41.1 & 58.9 \\
\hline Dark tern & Sterna fuscata / anaethetus & 118 & 100.0 & 0.0 \\
\hline Little shearwater & Puffinus assimilis & 19 & 52.6 & 47.4 \\
\hline Flesh-footed shearwater & Puffinus carneipes & 11 & 45.5 & 54.5 \\
\hline Black-bellied storm-petrel & Fregetta tropica & 8 & 100.0 & 0.0 \\
\hline Unidentified petrel & Procellaridae spp. & 6 & 33.3 & 66.7 \\
\hline Wilson's storm-petrel & Oceanites oceanicus & 5 & 60.0 & 40.0 \\
\hline Indian yellow-nosed albatross & Thallasarche carteri & 5 & 40.0 & 60.0 \\
\hline Long-tailed jaeger & Stercorarius longicaudus & 5 & 80.0 & 20.0 \\
\hline White-chinned petrel & Procellaria aequinoctialis & 4 & 50.0 & 50.0 \\
\hline Light-mantled sooty albatross & Phoebetria palpebrata & 3 & 100.0 & 0.0 \\
\hline White-faced storm-petrel & Pelagodroma marina & 2 & 100.0 & 0.0 \\
\hline Unidentified giant petrel & Macronectes spp. & 1 & 100.0 & 0.0 \\
\hline White-necked petrel & Pterodroma externa cervicalis & 1 & 0.0 & 100.0 \\
\hline $9 \mathrm{~km}$ survey bins & & 198 & 40.9 & 59.1 \\
\hline
\end{tabular}

Oceanographic data. We used altimetry data from the merged TOPEX/Poseidon and ERS product, with a spatial resolution of $0.25^{\circ}$ latitude/longitude and a $10 \mathrm{~d}$ repeat cycle, available from the Colorado Centre for Astrodynamics Research (CCAR) (www-ccar.colorado. edu). These altimetry data, which quantify the temporal variability in the height of the sea surface driven by changes in currents (location and speed) and eddies, are indicative of in situ surface and subsurface oceanographic conditions (Park \& Gambéroni 1995, Davis et al. 2002). We superimposed the survey transects over concurrent daily altimetry maps, and extracted the SSHA values for each $9 \mathrm{~km}$ survey bin. This approach assumes that the SSHA values at the centroid of each survey bin are representative of the conditions within an overlying $9 \mathrm{~km}$ segment of survey track.

We also relied on satellite imagery to characterize the 2D distributions and gradients in SST and chl a along the cruise track. To match the $10 \mathrm{~d}$ repeat cycle of the altimetry data, we created $10 \mathrm{~d}$ imagery composites for each survey day (January 17 to 21, 2003), by calculating the average SST and chl a pixel value during the same $10 \mathrm{~d}$ time period sampled by the satellite altimeter. We then matched the seabird survey bins to the imagery composites centered on the same day. That is, the composite spanned from $5 \mathrm{~d}$ before to $4 \mathrm{~d}$ after the seabird survey.

We used $9 \mathrm{~km}$ night Pathfinder SST imagery from the Advanced Very High Resolution Radiometer (AVHRR) (http://podaac.jpl.nasa.gov/pub/sea_surface_ temperature/avhrr/pathfinder/data_v4.1/), which on average underestimates in situ water temperatures by $0.09^{\circ} \mathrm{C}$ (Casey \& Cornillon 1999). We derived chl a along the cruise track from $9 \mathrm{~km}$ Sea-viewing Wide
Field-of-view Sensor (SeaWiFS) imagery (http://seawifs. gsfc.nasa.gov/SEAWIFS.html), which are within 35\% of in situ measurements in the range of 0.05 to $50 \mathrm{mg}$ $\mathrm{m}^{-3}$ (Hooker \& McClain 2000). The $9 \mathrm{~km}$ pixel size allowed us to co-register the SST and chl a imagery from the 2 different satellites. This resolution was comparable to the spatial scale $(\sim 10 \mathrm{~km}$ hydrographic station spacing) successfully used to characterize the temperature and color fronts at the periphery of mesoscale eddies (Ribic et al. 1997, Davis et al. 2002).

In addition to measuring the mean SST and chl a for each $9 \mathrm{~km}$ survey bin, we quantified the proportional change (PC) in these properties within a surrounding $27 \times 27 \mathrm{~km}(3 \times 3$ pixel $)$ grid. This gradient metric, which expresses the relative magnitude of change in the habitat variable scaled to the maximum value, ranges from 0 to $100 \%$ and is calculated as follows: $\mathrm{PC}=[$ (maximum value/minimum value $) \times$ 100]/(maximum value).

Scales of analysis. Because the cruise track was dissected by night-time periods of no survey effort, we combined adjacent $9 \mathrm{~km}$ survey bins into 5 disjunct transects (mean transect distance $=356.4 \pm 35.8 \mathrm{SD}$ ) (Table 2). We assessed the spatial scales (autocorrelation) of environmental variability along each daily transect using Pearson correlation coefficient for lags of 1 to 11 bins (9 to $99 \mathrm{~km}$ ) (Sokal \& Oden 1978). We defined the characteristic patch scale of each environmental variable (SST in units of ${ }^{\circ} \mathrm{C}$, chl $a$ in units of $\mathrm{mg}$ $\mathrm{m}^{-3}$, SSHA in units of $\mathrm{cm}$ ) as the point along the space domain where the correlogram first crossed the $x$-axis (correlation $=0$ ) (Reid et al. 2004).

Seabird response to mesoscale features. To quantify seabird associations with eddies, we contrasted the 
Table 2. Summary of environmental conditions and seabird sightings along the 5 daily transects across the southern Indian Ocean (January 17 to 21, 2003). DKTE: dark tern; GWPT: great-winged petrel; WTSH: wedge-tailed shearwater

\begin{tabular}{|c|c|c|c|c|c|c|c|c|c|c|c|c|c|}
\hline \multirow[t]{2}{*}{ Transect } & \multirow{2}{*}{$\begin{array}{l}\text { Survey } \\
\text { length } \\
(\mathrm{cm})\end{array}$} & \multirow{2}{*}{$\begin{array}{l}\text { SSHA } \\
\text { range } \\
(\mathrm{km})\end{array}$} & \multirow{2}{*}{$\begin{array}{l}\text { Hydrographic } \\
\text { feature }\end{array}$} & \multicolumn{3}{|c|}{ Mean $(\mathrm{CV})$} & \multicolumn{3}{|c|}{ —Patch scale $(\mathrm{km})$ - } & \multirow{2}{*}{$\begin{array}{l}\text { Mean abund. } \\
(\mathrm{CV}) \\
\text { (birds km-2) }\end{array}$} & \multirow{2}{*}{\multicolumn{3}{|c|}{$\begin{array}{c}\text { Proportional } \\
\text { abundance }(\%)\end{array}$}} \\
\hline & & & & $\begin{array}{l}\mathrm{SSH} \\
(\mathrm{cm})\end{array}$ & $\begin{array}{l}\text { SST } \\
\left({ }^{\circ} \mathrm{C}\right)\end{array}$ & $\begin{array}{c}\mathrm{Chl} \mathrm{a} \\
\left(\mathrm{mg} \mathrm{m}^{-3}\right)\end{array}$ & $\begin{array}{l}\mathrm{SSH} \\
(\mathrm{cm})\end{array}$ & $\begin{array}{l}\text { SST } \\
\left({ }^{\circ} \mathrm{C}\right)\end{array}$ & $\begin{array}{c}\mathrm{Chl} \mathrm{a} \\
\left(\mathrm{mg} \mathrm{m}^{-3}\right)\end{array}$ & & & & \\
\hline 1 & 387 & $-0.7 / 3.5$ & $\begin{array}{c}\text { Weak } \\
\text { convergence }\end{array}$ & +1.08 (129.9) & $18.03(2.1)$ & $0.18(11.5)$ & 72 & 90 & 63 & $0.69(96.4)$ & 0.0 & 88.9 & 0.0 \\
\hline 2 & 378 & $-3.7 / 2.7$ & $\begin{array}{l}\text { Weak } \\
\text { dipole }\end{array}$ & $-0.55(352.0)$ & $18.34(1.0)$ & $0.13(10.8)$ & 72 & 36 & 72 & $0.76(120.5)$ & 0.0 & 86.2 & 0.0 \\
\hline 3 & 369 & $-9.2 /-0.1$ & $\begin{array}{l}\text { Strong } \\
\text { divergence }\end{array}$ & $-4.17(51.0)$ & $18.84(1.7)$ & $0.25(29.9)$ & 135 & 54 & 90 & $0.73(120.9)$ & 0.0 & 90.0 & 0.0 \\
\hline 4 & 351 & $-5.7 / 1.3$ & $\begin{array}{l}\text { Cyclone } \\
\text { edge }\end{array}$ & $-2.26(103.8)$ & $19.85(2.9)$ & $0.07(17.0)$ & 81 & 135 & 135 & $0.84(114.2)$ & 0.0 & 79.8 & 1.1 \\
\hline 5 & 297 & $-1.1 / 6.7$ & $\begin{array}{l}\text { Anticyclone } \\
\text { edge }\end{array}$ & $+2.67(96.8)$ & $20.49(2.8)$ & $0.12(12.6)$ & 63 & 108 & 108 & $11.48(305.4)$ & 11.50 & 5.8 & 80.4 \\
\hline
\end{tabular}

incidence (e.g. presence/absence) and the abundance of the 3 focal taxa within 4 types of mesoscale features, defined on the basis of SSHA (Ribic et al. 1997, Davis et al. 2002): anticyclones $(>+10 \mathrm{~cm})$, cyclones $(<-10 \mathrm{~cm})$, convergence zones $(0$ to $+10 \mathrm{~cm})$, and divergence zones $(0$ to $-10 \mathrm{~cm})$.

Multivariate seabird habitats. To determine which oceanographic conditions most strongly influenced the distribution of the 3 focal taxa, we used logistic regression to relate bird occurrence (binary dependent variable, presence/absence) to 6 continuous predictor variables: SSHA (cm), chl a $\left(\mathrm{mg} \mathrm{m}^{-3}\right)$, chl a gradients $(\%)$, SST $\left({ }^{\circ} \mathrm{C}\right), \mathrm{SST}$ gradients $(\%)$, and the distance to Western Australia $(\mathrm{km})$, where an estimated 2 million wedge-tailed shearwaters and 500000 sooty terns breed (Surnam \& Wooller 2003).

Before we analyzed the seabird-eddy associations, we accounted for the potential autocorrelation in the distributions of the 3 focal taxa and for co-variation in the explanatory environmental variables (Tabachnik \& Fidell 1996). We quantified the co-variation of the 6 environmental variables using pair-wise Spearman rank correlations. We also tested whether the $9 \mathrm{~km}$ survey bins represented independent sampling units. We quantified whether the presence/absence of each focal taxa within contiguous survey bins was correlated using the joint-count statistic (Sokal \& Oden 1978). We used the Rookcase Excel Add-In software, with the rook adjacency rule, to compute the observed and expected number of presence/presence, absence/ absence, and presence/absence events, given the total number of bird occurrences along the track (Sawada 1999). Under the null hypothesis of no autocorrelation (independent seabird sightings along the survey track), the observed and expected counts should not differ. Conversely, if the birds aggregate into patches, subsequent observations will be dependent on previous sightings, and the observed and expected frequen- cies should differ. We contrasted these proportions for each transect separately using G-tests.

\section{RESULTS}

\section{Oceanographic observations}

Our cruise track spanned a heterogeneous subtropical (SST $>17^{\circ} \mathrm{C}$ ) seascape, with each daily transect surveying distinct hydrographic conditions (Table 2). Transect 1 spanned a region of weak convergence, with a small SSHA range $(4.2 \mathrm{~cm})$ and intermediate $\mathrm{chl}$ a $($ mean $=$ $0.18 \mathrm{mg} \mathrm{m}^{-3}$ ). Transect 2 crossed a weak dipole, a warmcore and a cold-core eddy pair, as evidenced by the variable SSHA conditions (range $=6.4 \mathrm{~cm}, \mathrm{CV}=352 \%$ ). Transect 3 surveyed a region of strong divergence, characterized by a broad range of SSHA values $(9.1 \mathrm{~cm})$, a large magnitude negative mean SSHA $(-4.2 \mathrm{~cm})$, and the highest chl a observed during the cruise (mean = $0.25 \mathrm{mg} \mathrm{m}^{-3}$ ). Transects 4 and 5 sampled the edges of a cyclone (divergence) and an anticyclone (convergence), respectively. Overall, we sampled regions of surface convergence and divergence, with SSHA values ranging from -9.2 to $+6.7 \mathrm{~cm}$. Because we did not survey the core of any anticyclones $(\geq+10 \mathrm{~cm})$ or cyclones $(\leq-10 \mathrm{~cm})$, our analysis focuses on convergence (SSHA $>0$ ) and divergence (SSHA < 0) zones (Davis et al. 2002).

The spatial patterns of SSHA varied across the 5 daily transects. The region of strong divergence (Transect 3) was characterized by the largest patch scale $(135 \mathrm{~km})$, and the edge of the anticyclone (Transect 5) was characterized by the smallest $(63 \mathrm{~km})$. The scales of SSHA variability along the other 3 transects were intermediate, with the weak convergence (Transect 1), the weak dipole (Transect 2), and the edge of the cyclone (Transect 4) having patch scales of 81, 81 and $72 \mathrm{~km}$, respectively (Table 2 ). 


\section{Seabird observations}

We surveyed $1782 \mathrm{~km}$ of cruise track over $5 \mathrm{~d}$, sighted 1361 seabirds belonging to 17 taxa, and identified $91.8 \%$ to species level (Table 1). To avoid misidentifications, we combined the counts of sooty Sterna fuscata, bridled $S$. anaethetus, and unidentified dark $S$. fuscata or $S$. anaethetus terns, which accounted for $8.5,2.5$, and $89.0 \%$, respectively, of dark-colored tern sightings, into what we termed 'dark terns'. However, those flocks that we approached closely enough to obtain definite speciesspecific identification, contained both sooty and bridled terns. Wedge-tailed shearwater Puffinus pacificus, great-winged petrels Pterodroma macroptera, and dark terns were the 3 most numerous taxa, accounting for approximately $95 \%$ of all the sighted birds. The extent to which these species followed the ship was negligible, with the 3 focal taxa showing vessel attraction indices (AI) of -1, indicating that they were not recorded following the vessel (K. D. Hyrenbach et al. unpubl.).

The behaviors of the 3 focal species differed significantly. The shearwaters were sighted feeding $(45.08 \%)$ and sitting on the water $(41.56 \%)$ in similar proportions, and were less frequently seen in flight $(13.36 \%)$. About 3 quarters of all the petrels sighted were in flight $(74.07 \%)$, with the rest sitting on the water $(21.37 \%)$, and feeding $(4.56 \%)$. Almost all of the terns we sighted were feeding $(98.31 \%)$, with the rest $(1.69 \%)$ in flight. The incidence of feeding ( $G$-test: $G=$ 154.75, $\mathrm{df}=2, \mathrm{p}<0.001)$ and flying $(G=223.93, \mathrm{df}=2$, $\mathrm{p}<0.001$ ) differed significantly across the 3 focal taxa.

Overall, seabird abundance (all species combined) increased from west to east, with the highest densities off Western Australia (Table 2). In particular, Transect 5 was characterized by bird densities that were an order of magnitude (10 times) higher. Additionally, the wedge-tailed shearwater replaced the great-winged petrel as the numerically dominant species off Western Australia (Transect 5).

\section{Ocean habitats}

The environmental variables considered in this analysis were cross-correlated (Table 3 ). Of the 15 possible pairwise comparisons, 8 yielded significant results $(\mathrm{p}<0.05)$. SSHA was correlated positively with SST and negatively with chl $a$, suggesting that areas of surface divergence were characterized by 'greener' and cooler waters. SSHA was also negatively correlated with gradients in SST and chl $a$, indicating that regions with strong surface divergence (e.g. Transect 3) were more homogeneous. Furthermore, chl a and SST were negatively correlated, suggesting that regions of localized upwelling supported enhanced primary productivity. We did not detect significant spatial trends in SSHA or in the gradients of SST and chl $a$ along the cruise track, as revealed by the lack of significant correlations between these variables and the distance from Western Australia. We did, however, document 'greener' (higher chl a) and cooler (lower SST) waters to the west, farther from Western Australia. Finally, SST gradients were marginally $(0.10>p>0.05)$ correlated with SST, indicating that warmer regions were characterized by lower temperature gradients.

\section{Seabird-SSHA associations}

Overall, 81 (40.9\%) and 117 (59.1\%) of the $9 \mathrm{~km}$ survey bins occurred in convergence and divergence zones, respectively. When we contrasted the relative occurrence (presence/absence) and abundance of seabirds within convergences (SSHA $>0$ ) and divergences (SSHA $<0$ ), 2 focal taxa showed significant associations. For the wedge-tailed shearwater, the number of occurrences $(73.7 \%)$ and birds sighted $(89.2 \%)$ were disproportionately more numerous within convergence zones ( $G$-test, $\mathrm{df}=1, \mathrm{p}<0.001$ for both comparisons). This pattern was even more extreme for the tern, which occurred exclusively in convergence zones ( $G$-test, $\mathrm{df}=1, \mathrm{p}<0.001$ for both comparisons). For the great-winged petrel, the number of occurrences $(42.0 \%)$ and individuals $(41.1 \%)$ within convergence zones were proportional to the survey effort $(40.9 \%)$, suggesting that there were no significant differences in their relative sighting rates or abundances across hydrographic features (G-test, $\mathrm{df}=1, \mathrm{p}>0.50$ for both comparisons).

Table 3. Summary of cross-correlations between the environmental variables used to characterize seabird distributions. Chlorophyll a (chl a) concentration, sea surface temperature (SST), sea surface height anomaly (SSHA), distance to Western Australia (DIST), temperature gradient (TGR), and chlorophyll gradient (CGR). For each pair-wise combination, the matrix shows the sign and the magnitude of the Spearman rank correlation coefficient, and the associated significance level. The bold font denotes significant results $\left(r_{s}\right.$ critical $=0.138$,

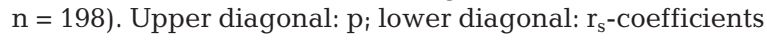

\begin{tabular}{|lcccccc|}
\hline & Chl $a$ & SST & SSHA & DIST & TGR & CGR \\
\hline Chl $a$ & - & $<\mathbf{0 . 0 0 1}$ & $\mathbf{0 . 0 5}-\mathbf{0 . 0 2}$ & $<\mathbf{0 . 0 0 1}$ & $\mathbf{0 . 0 2 - 0 . 0 1}$ & $0.50-0.20$ \\
SST & $\mathbf{- 0 . 4 0 8}$ & - & $\mathbf{0 . 0 5}-\mathbf{0 . 0 2}$ & $<\mathbf{0 . 0 0 1}$ & $0.10-0.05$ & $0.50-0.20$ \\
SSHA & $\mathbf{- 0 . 1 4 7}$ & $\mathbf{+ 0 . 1 4 8}$ & - & $>0.50$ & $<\mathbf{0 . 0 0 1}$ & $\mathbf{0 . 0 5}-\mathbf{0 . 0 2}$ \\
DIST & $\mathbf{+ 0 . 3 7 3}$ & $\mathbf{- 0 . 9 1 1}$ & +0.022 & - & $>0.50$ & $0.50-0.20$ \\
TGR & $\mathbf{+ 0 . 1 7 2}$ & -0.122 & $\mathbf{- 0 . 2 8 9}$ & +0.042 & - & $>0.50$ \\
CGR & +0.079 & -0.059 & $\mathbf{- 0 . 1 4 5}$ & +0.063 & +0.012 & - \\
\hline
\end{tabular}




\section{Multivariate seabird habitats}

The autocorrelation analyses for the 3 focal taxa revealed no significant patterns for the shearwater (Transect 5, $G=2.633,0.50>\mathrm{p}>0.25$ ), for the petrel (Transects 1 to 5, $G=0.179-4.673, \mathrm{p}>0.05$ for all 5 comparisons), or for the tern (Transect 5, $G=0.281$, $0.90>\mathrm{p}>0.75)(G$-critical $=5.991, \mathrm{df}=2$ for all compar isons). Thus, we considered the $9 \mathrm{~km}$ survey bins as independent samples for the logistic regression analysis. To account for the cross-correlations between the environmental variables (Table 3), we used a step-wise approach to assemble the best-fit model iteratively, by rejecting/retaining the variables with the lowest/highest explanatory power one at a time (Davis et al. 2002).

The best-fit forwards and backwards step-wise models selected the same explanatory variables. A different environmental variable was selected for each focal taxon, with SSHA not being incorporated into any of the best-fit models. The shearwater and the tern were more numerous in warm SST waters closer to Western Australia (Table 4). For these 2 taxa, the best-fit models were highly significant and explained over $90 \%$ of their occurrences. In contrast, the petrel was only marginally correlated ( $p=0.087$ ) with SST gradients, with the best-fit model only correctly assigning $55.9 \%$ of its occurrences along the cruise track.

\section{DISCUSSION}

There is mounting evidence that mesoscale eddies are characterized by enhanced ocean productivity, the retention of zooplankton, and the aggregation of sea turtles, predatory fishes, cetaceans, and seabirds ( Nel et al. 2001, Seki et al. 2001, 2002, Davis et al. 2002, Polovina et al. 2004). Previous studies, however, have often focused on the significance of specific hydrographic features (e.g. cyclonic eddies) defined using a single habitat variable (e.g. SST, SSHA). Nevertheless, because mesoscale eddies are characterized by strong gradients in water mass properties (e.g. temperature and color fronts), it is inherently difficult to determine which hydrographic features most strongly influence seabird distributions (Haney \& McGillivary 1985, Haney 1986b, Strass 1992, Seki et al. 2001). This is particularly the case along the periphery of eddies, where many pelagic predators forage ( $\mathrm{Nel}$ et al. 2001, Polovina et al. 2004, Weimerskirch et al. 2004).

In the present study, we used 2 approaches to assess the association of subtropical seabirds with mesoscale eddies. We first compared the relative occurrence (presence/absence) and abundance (proportion of individuals) of 3 focal taxa within convergence and divergence zones. Next, we used a step-wise procedure to determine which environmental variables, including SSHA and SST/chl a gradients, most accurately characterized seabird distributions across our study area.

These comparisons revealed statistically significant associations for 2 taxa. The wedge-tailed shearwater, which was restricted to the 2 eastern most transects (4 and 5), occurred disproportionately more frequently and in higher abundances within convergence regions (SSHA > 0). The logistic regression model selected the distance to Western Australia as the best predictor of wedge-tailed shearwater occurrence within the study area, highlighting the importance of this major breeding colony location as a determinant of the oceanic distribution of this species in the eastern Indian Ocean (Table 4). The wedge-tailed shearwater ranges throughout the tropical and subtropical Indian Ocean, and breeds to the east and west of the study area, though not on Amsterdam or St. Paul islands (Harrison 1987). An estimated 2 million of these birds breed off Western Australia $\left(115-116^{\circ} \mathrm{E}, 31-36^{\circ} \mathrm{S}\right)$, where they are the most numerous shearwater species during summer (Surnam \& Wooller 2000, 2003). Previous studies suggest that this species breeds during the summer, and feeds predominantly on fish and squid, often in association with subsurface predators (dolphins, tunas) (Harrison et al. 1983, Jaquemet et al. 2004). During the cruise of the present study, these shearwaters most commonly occurred as solitary birds, though they also aggregated into large

Table 4. Results of the step-wise logistic regression, describing the occurrence (presence/absence) for the wedge-tailed shearwater (WTSH), the great-winged petrel (GWPT), and the dark tern (DKTE). For each focal taxa, the significant variables, the associated test statistic and significance levels, and the qualitative description of the model results are shown. Additionally, the log-likelihood results and the proportion of the observations correctly assigned by the best-fit model are reported. WA: Western Australia; SST: sea surface temperature

\begin{tabular}{|c|c|c|c|c|c|c|c|c|c|}
\hline Focal taxon & Variable & $\begin{array}{c}\text { Coefficient } \\
( \pm \text { SE })\end{array}$ & $t$-ratio & $\mathrm{p}$ & Result & Log likelihood & $\mathrm{df}$ & $\mathrm{p}$ & $\begin{array}{c}\text { Correct } \\
(\%)\end{array}$ \\
\hline WTSH & Distance WA & $-0.007 \pm 0.003$ & -2.614 & 0.009 & Closer to WA & 74.070 & 1 & $<0.001$ & 91.4 \\
\hline GWPT & Temp. gradient & $-0.165 \pm 0.096$ & -1.714 & 0.087 & Homogeneous SST & 2.949 & 1 & 0.086 & 55.9 \\
\hline DKTE & SST & $+2.602 \pm 1.211$ & +2.148 & 0.032 & Warm SST & 14.815 & 1 & 0.022 & 97.5 \\
\hline
\end{tabular}


feeding flocks (median number of birds per sighting $=1$, range $=1$ to $200, \mathrm{n}=67$ sightings).

While dark terns were only sighted within convergence zones, the multivariate analysis revealed that their distribution was most closely related to the higher SST (Table 4). This result is consistent with evidence from the mid-Atlantic United States, where bridled terns aggregated within warm filaments associated with the Gulf Stream (Haney 1986a). Both sooty and bridled terns range and breed throughout the tropical Indian Ocean, though only rarely on Amsterdam or St. Paul islands (Harrison 1987). An estimated 250000 pairs of sooty terns breed on islands off Western Australia, where their diet consists of cephalopods, euphausiids, and fish (Surnam \& Wooller 2003). Some of these prey species concentrate at convergence zones along the periphery of anti-cyclonic eddies (e.g. myctophids, Olson \& Backus 1985) and fronts (e.g. by-thewind-sailor Velella velella, Polovina et al. 2004). Additionally, sooty terns often forage in association with subsurface predators (dolphins, tunas) (Jaquemet et al. 2004). During our cruise, these terns sometimes aggregated into large feeding flocks (median number of birds per sighting $=3.5$, range $=1$ to $100, \mathrm{n}=8$ sightings).

The third focal species, the great-winged petrel, was widely distributed across the study area (Table 2), with neither its occurrence nor its abundance being significantly related to SSHA. Moreover, the multivariate analysis revealed that the distribution of this petrel was most strongly related to homogeneous areas of low SST gradients (Table 4). These results are consistent with the natural history and the foraging ecology of this species. Great-winged petrels breed in winter to the east (Western Australia) and to the west (Kerguelen) of the study area, and are broadly distributed throughout the subtropical Indian Ocean (Harrison 1987, Surnam \& Wooller 2000). This species feeds primarily on cephalopods, and secondarily on fish and crustaceans, captured at the sea surface (Harper et al. 1985). However, because many of its prey are vertically migrating meso-pelagic species (myctophid fishes, ommastrephid squids, euphausiid crustaceans), Imber (1973) hypothesized that this petrel scavenges buoyant squid during the day and takes bioluminescent prey at night. Thus, we would expect this species to forage along convergence zones, where buoyant carcasses should become concentrated. However, our analysis suggests that this species does not associate with specific oceanographic habitats, at least in the daytime. During the cruise of the present study, we largely sighted solitary petrels (median number of birds per sighting $=1$, range $=1$ to $5, \mathrm{n}=276$ sightings) engaged in flight $(74.07 \%)$ or sitting on the water $(21.37 \%)$. The nocturnal feeding habits of this species may be responsible for the very low incidence of feed- ing behaviour $(4.56 \%)$, its dispersed distribution, and the lack of an association with mesoscale eddies or finer-scale hydrographic features.

Our exploratory analysis offers 3 conclusions concerning the study of seabird-eddy associations. First, it highlights the need to clearly define and characterize mesoscale hydrographic features on the basis of quantitative remotely sensed or in situ oceanographic measurements (e.g. SSHA, thermocline depth), and to consider smaller-scale convergence and divergence regions in addition to large sized eddies (Ribic et al. 1997, Davis et al. 2002, Weimerskirch et al. 2004). For instance, in this study we considered 4 types of mesoscale features, defined in terms of SSHA: anticyclones $(\geq+10 \mathrm{~cm})$, cyclones $(\leq-10 \mathrm{~cm})$, convergence zones (from 0 to $+10 \mathrm{~cm}$ ), and divergence zones (from 0 to $-10 \mathrm{~cm}$ ). Additionally, we characterized the heterogeneous nature of these mesoscale features by quantifying the variability in SSHA characteristics (e.g. patch scale, magnitude).

Second, our results stress the importance of considering the influence of finer-scale water mass properties, such as temperature and color fronts. In particular, frontal meanders and jets give rise to smaller-scale convergences and divergences, which in turn concentrate upper-trophic predators and their prey (Haney 1986a, Fiedler \& Bernard 1987, Polovina et al. 2004). In spite of their short-lived nature, these ephemeral fronts may enhance foraging opportunities for upper-trophic predators (Pitman \& Ballance 1990, Podesta et al. 1993), particularly in pelagic systems where prey patches are over-dispersed. Because eddies are characterized by gradients in SST and chl $a$, it may be difficult to ascribe upper-trophic predator occurrence and aggregation solely to the presence of mesoscale eddies (Haney \& McGillivary 1985, Davis et al. 2002, Polovina et al. 2004). To deal with these confounding factors, it is essential to quantify the co-variation of the environmental variables, and to use multivariate statistical approaches capable of separating the influence of each individual factor. In this study, univariate analyses suggested that 2 focal taxa aggregated at convergence zones (SSHA > 0). However, the multivariate analyses revealed that these seabirds were more strongly associated with other environmental variables.

Third, it is worth noting that remote sensing imagery can only provide a 2D perspective of 3D mesoscale eddies, and the associated smaller-scale fronts and convergence/divergence zones (Weller 1985, Franks 1992). However, much of the biological enhancement resulting from the presence of mesoscale eddies and frontal features takes place below the surface, where they cannot be monitored using satellite sensors (Strass 1992, Seki et al. 2002). Therefore, mechanistic studies are required to better understand the physical-biological coupling and the links between lower and upper trophic eco- 
system constituents that take place at eddies and other mesoscale features.

In summary, this study underscores the need to consider seabird-eddy associations in a broader oceanographic context. It is critical to consider the largescale $(1000 \mathrm{~s} \mathrm{~km})$ patterns of mesoscale variability across ocean basins, which are influenced by ocean currents (Park \& Gambéroni 1995). In contrast with previous studies which have focused on dynamic frontal regions (e.g. Gulf Stream fronts off the outheastern United States; Haney 1986) and energetic current systems (e.g. Agulhas Return Current off East Africa, Abrams \& Lutjeharms 1986), we surveyed a region of weak mesoscale variability north of the Subtropical Convergence zone (Fig. 2). Our study found that 2 of the 3 focal species we considered (wedge-tailed shearwater and dark terns) concentrated along convergence zones, even though these associations were not significant when we included additional habitat variables in the analysis. This result raises a question about the extent to which oceanic birds exploit mesoscale hydrographic features in subtropical regions. Comparative studies of seabird-eddy associations within regions of enhanced and diminished mesoscale activity are needed to gain a broader understanding of the global significance of these habitat features for oceanic birds (Haney 1986a, Hunt \& Schneider 1987).

Because eddy formation is only one of a number of physical processes that arise in dynamic water mass boundaries, it is critical to incorporate an understanding of the smaller-scale $(10 \mathrm{~s} \mathrm{~km})$ interactions of eddies with adjacent features (e.g. ocean currents, fronts). In particular, recent modelling efforts suggest that the entrainment of cool nutrient-rich waters from a coldcore cyclone into an adjacent warm-core anticyclone stimulates high primary and secondary productivity, and the aggregation of biomass along the outer edges and trailing filaments of eddies (Logerwell et al. 2001, Lima et al. 2002). Interestingly, satellite tracking studies have revealed that surface feeding albatrosses and frigatebirds forage for squid and fish along the periphery of warm-core eddies, while avoiding the highest SSHA areas at the center (Nel et al. 2001, Weimerskirch et al. 2004).

Future studies should consider the spatial variability in mesoscale variability across ocean basins (e.g. boundary currents vs. subtropical gyres), the spatial heterogeneity within eddies (e.g. periphery vs. core) and the variability across features (e.g. age, size, vorticity). These attributes may account for the high variability observed in the extent of seabird aggregation at eddies (Haney 1986a,b). In particular, the 'history' of an eddy (e.g. water mass of origin, interactions with other mesoscale features) likely influences its productivity, and biotic communities (e.g. for discussion of Gulf Stream anticyclonic eddies see Endo \& Wiebe 2005).

Acknowledgements. We are grateful to the officers and crew of the RV 'Marion Dufresne', to the French Polar Institute Paul-Emile Victor (IPEV, Programme no. 109), and to the French Ocean Indien Service d'Observation (OISO) program for facilitating our participation in this cruise. The U.S. National Science Foundation Office of Polar Programs supported GLH and KDH (NSF grant OPP - 0234570) and RRV (NSF grant OPP - 9983751). The remote sensing imagery originates from the Colorado Centre for Astrodynamics Research, the AVISO program, the Jet Propulsion Lab's Pathfinder product, and the SeaWiFS program. Three anonymous reviewers greatly improved this manuscript.

\section{LITERATURE CITED}

Abrams RW, Lutjeharms JRE (1986) Relationships between seabirds and mesoscale hydrographic features in the Agulhas current retroflection region. In: Ouellet $\mathrm{H}$ (ed) Proc XIX Int Ornithol Congr. University of Ottawa Press, Ottawa, p 991-996

Casey KS, Cornillon P (1999) A comparison of satellite and in situ-based sea surface temperature climatologies. J Clim 12:1848-1863

Davis RW, Ortega-Ortiz JG, Ribic CA, Evans WE and 6 others (2002) Cetacean habitat in the northern oceanic Gulf of Mexico. Deep-Sea Res I 49:121-142 
Endo Y, Wiebe PH (2005) Euphausiid distribution, abundance and succession in North Atlantic warm-core ring 82B. J Plankton Res 27:175-188

Fiedler PC, Bernard H (1987) Tuna aggregation and feeding near fronts observed in satellite imagery. Cont Shelf Res $7(8): 871-881$

Fiedler PC, Philbrick V, Chavez F (1991) Oceanic upwelling and productivity in the Eastern Tropical Pacific. Limnol Oceanogr 36:1834-1850

Franks PJS (1992) Sink or swim - accumulation of biomass at fronts. Mar Ecol Prog Ser 82:1-12

Haney JC (1986a) Seabird affinities for Gulf Stream frontal eddies: responses of mobile marine consumers to episodic upwelling. J Mar Res 44:361-384

Haney JC (1986b) Seabird segregation at Gulf Stream frontal eddies. Mar Ecol Prog Ser 28:279-285

Haney JC, McGillivary PA (1985) Aggregation of Cory Shearwaters (Calonectris diomedea) at Gulf Stream fronts. Wilson Bull 97:191-200

Harper PC, Croxall JP, Cooper J (1985) A guide to foraging methods used by marine birds in Antarctic and SubAntarctic seas. Biomass Handbook 24:1-22

Harrison CS, Hida TS, Seki MP (1983) Hawaiian seabird feeding ecology. Wildl Monogr 85:1-71

Harrison P (1987) Seabirds of the world: an identification guide. Houghton Mifflin, Boston, MA

Hooker SB, McClain CR (2000) The calibration and validation of SeaWiFS data. Prog Oceanogr 45(3-4):427-465

Hunt GL Jr, Schneider DC (1987) Scale dependent processes in the physical and biological environment of seabirds. In: Croxall JP (ed) The feeding ecology of seabirds and their role in marine ecosystems. Cambridge University Press, Cambridge, p 7-41

Imber MJ (1973) The food of grey-faced petrels (Pterodroma macroptera Gouldi (Hutton)), with species reference to diurnal vertical migration of their prey. J Anim Ecol 42: 645-662

Jaquemet S, Le Corre M, Weimerskirch H (2004) Seabird community structure in a coastal tropical environment: importance of natural factors and fish aggregating devices (FADs). Mar Ecol Prog Ser 268:281-292

Lima ID, Olson DB, Doney SC (2002) Biological response to frontal dynamics and mesoscale variability in oligotrophic environments: biological production and community structure. J Geophys Res - Oceans 107(C8):3111

Logerwell EA, Lavaniegos B, Smith PE (2001) Spatiallyexplicit bioenergetics of Pacific sardine in the Southern California Bight: are mesoscale eddies areas of exceptional prerecruit production? Prog Oceanogr 49:391-406

McGillicuddy DJ, Robinson AR, Siegel DA, Jannasch HW and 5 others (1998) Influence of mesoscale eddies on new production in the Sargasso Sea. Nature 394:263-266

Nel DC, Lutjeharms JRE, Pakhomov EA, Ansorge IJ, Ryan PG, Klages NTW (2001) Exploitation of mesoscale oceanographic features by grey-headed albatross Thalassarche chrysostoma in the southern Indian Ocean. Mar Ecol Prog Ser 217:15-26

Olson DB, Backus RH (1985) The concentration of organisms at fronts: a cold-water fish and a warm-core ring. J Mar Res 43:113-137

Oschlies A, Garcon V (1998) Eddy-induced enhancement of primary production in a model of the North Atlantic Ocean. Nature 394:266-269

Owen RW (1981) Fronts and eddies in the sea: mechanisms, interactions and biological effects. In: Longhurst AR (ed) Analysis of marine ecosystems. Academic Press, New York, p 197-231
Park YH, Gambéroni, L (1995) Large-scale circulation and its variability in the South Indian Ocean from TOPEX/ POSEIDON altimetry. J Geophys Res - Oceans 100(C12): 24911-24929

Pitman RL, Ballance LT (1990) Daytime feeding by Leach's Storm-petrel on a midwater fish in the ETP. Condor 92: $524-527$

Podesta GP, Browder JA, Hoey JJ (1993) Exploring the association between swordfish catch rates and thermal fronts on U.S. longline grounds in the western North Atlantic. Cont Shelf Res 13:253-277

Polovina JJ, Balazs GH, Howell EA, Parker DM, Seki MP, Dutton PH (2004) Forage and migration habitat of Loggerhead (Caretta caretta) and Olive Ridley (Lepidochelys olivacea) sea turtles in the central North Pacific Ocean. Fish Oceanogr 13:36-51

Reid K, Sims M, White RW, Gillon KW (2004) Spatial distribution of predator/prey interactions in the Scotia Sea: implications for measuring predator / fisheries overlap. DeepSea Res II 51:1383-1396

Ribic CA, Davis R, Hess N, Peake D (1997) Distribution of seabirds in the northern Gulf of Mexico in relation to mesoscale features: initial observations. ICES J Mar Sci 54 (4):545-551

Robinson, AR (1983) Overview and summary of eddy science. In: Robinson AR (ed) Eddies in marine science. SpringerVerlag, New York, p 3-15

Sawada M (1999) Rookcase: an excel 97/2000 visual basic add-in for exploring global and local spatial autocorrelation. Bull Ecol Soc Am 80:231-234

Seki MP, Polovina JJ, Brainard RE, Bidigare RR, Leonard CL, Foley DG (2001) Biological enhancement at cyclonic eddies tracked with GOES thermal imagery in Hawaiian waters. Geophys Res Lett 28:1583-1586

Seki MP, Lumpkin R, Flament P (2002) Hawaii cyclonic eddies and blue marlin catches: the case study of the 1995 Hawaiian International Billfish Tournament. J Oceanogr 58:739-745

Sokal RR, Oden NL (1978) Spatial autocorrelation in biology. I. Methodology. Biol J Linn Soc 10:199-228

Strass VH (1992) Chlorophyll patchiness caused by mesoscale upwelling at fronts. Deep-Sea Res I 39:75-96

Surman CA, Wooller RD (2000) Seabirds off the south-western coast of Australia. Emu 100:312-317

Surman CA, Wooller RD (2003) Comparative foraging ecology of five sympatric terns at a sub-tropical island in the eastern Indian Ocean. J Zool 259:219-230

Tabachnick BG, Fidell LS (1996) Using multivariate statistics, 3rd edn. Harper Collins College Publishers, Northridge, CA

Tasker ML, Hope-Jones P, Dixon T, Blake BF (1984) Counting seabirds at sea from ships: a review of methods and a suggestion for a standardized approach. Auk 101:567-577

Uda M, Ishino M (1958) Enrichment pattern resulting from eddy systems in relation to fishing grounds. J Tokyo Univ Fish 44:105-129

Weimerskirch H, Le Corre M, Jaquemet S, Potier M, Marsac F (2004) Foraging strategy of a top predator in tropical waters: great frigatebirds in the Mozambique Channel. Mar Ecol Prog Ser 275:297-308

Weller R (1985) Three dimensional flow in the ocean. Science 227:1552-1556

Yoder JA, Atkinson LP, Lee TN, Kim HH, McLain CR (1981) Role of Gulf Stream frontal eddies in forming phytoplankton patches on the outer southeast shelf. Limnol Oceanogr 26:1103-1110

Yoder JA, Ackleson SG, Barber RT, Flamen P, Balch WM (1994) A line in the sea. Nature 371:689-692

Submitted: July 7, 2005; Accepted: March 6, 2006

Proofs received from author(s): September 20, 2006 